\title{
O BRASIL E O FMI DESDE BRETTON WOODS: 70 ANOS DE HISTÓRIA*
}

\author{
Paulo Roberto de Almeida \\ BRAZIL AND IMF SINCE BRETTON WOODS: A 70 YEARS HISTORY
}

\section{RESUMO}

O OBJETIVO DESTE ENSAIO HISTÓRICO É O DE ACOMPANHAR O RELACIONAMENTO DO BRASIL COM O FMI, NO CONTEXTO DA EVOLUÇÃO DO SISTEMA MONETÁRIO INTERNACIONAL, DESDE BRETTON WOOdS ATÉ A ATUALIDADE. O ENSAIO COMEÇA POR RETRAÇAR O ITINERÁRIO DO FMI, COM DESTAQUE PARA A MUDANCCA DE PADRÃO CAMBIAL EM 1971, E SEGUE COM O EXAME DAS RELAC ÕES ENTRE O BRASIL E A INSTITUIÇÃO, COM ÊNFASE NOS ACORDOS CONTRAÍDOS SOB DIFERENTES POLÍTICAS ECONÔMICAS E EM MOMENTOS DIVERSOS DE CRISES NAS TRANSACÕES EXTERNAS; O PRIMEIRO ACORDO FOI ROMPIDO POR RAZÕES POLÍTICAS EM 1958, E O MAIS RECENTE, DE 2003, FOI SUSPENSO EM 2005, ANTES DE SUA CONCLUSÃO, TAMBÉM POR MOTIVOS POLÍTICOS. SÃO DESTACADOS OS PROBLEMAS ENFRENTADOS PELO FMI NO PERÍODO - ESTABILIDADE CAMBIAL, LIQUIDEZ, MONITORAMENTO DAS ECONOMIAS NACIONAIS - E AS CIRCUNSTÂNCIAS QUE LEVARAM O BRASIL A CONTRAIR SEUS MUITOS ACORDOS COM A INSTITUIÇÃO. O PAís MANTEVE UMA RELAC̣ĀO ERRÁTICA COM O FMI, COM APROXIMAC̄ÕES E DISTANCIAMENTOS AO LONGO DO PERÍODO, OSCILANDO ENTRE UMA POSTURA COOPERATIVA - NO INÍCIO E DURANTE A MAIOR PARTE DO REGIME MILITAR, BEM COMO NO FINAL DOS ANOS 1990 E INÍCIO DO NOVO MILÊNIO -, E UMA OUTRA DE REJEIÇÃO OU CONFRONTAÇÃO NO GOVERNO KUBITSCHEK E NA REDEMOCRATIZAÇÃO -, FINALIZANDO POR UMA PASSAGEM DA SITUAÇĀO DE DEVEDOR DEPENDENTE, NA MAIOR PARTE DESSE LONGO PERÍODO, A UMA DE CREDOR E DEMANDANTE POR REFORMAS NA INSTITUIÇÃO, NA FASE RECENTE, QUANDO O PAÍS BUSCA AUMENTAR SEU PODER DE VOTO NAS INSTITUIÇÕES DE BRETTON WOODS; UMA TABELA FINAL LISTA OS ACORDOS CONCLUÍdOS PELO BRASIL COM O FMI E OS VALORES ENVOLVIDOS EM CADA UM.

\section{PALAVRAS-CHAVE}

BRASIL; FMI; ACORDOS; REGIMES CAMBIAIS; DÍVIDA EXTERNA; CRISES DE TRANSAC ÕES CORRENTES.

\begin{abstract}
THE PURPOSE OF THIS HISTORICAL ESSAY IS TO FOLLOW BRAZIL'S RELATIONSHIP WITH IMF, IN THE CONTEXT OF THE INTERNATIONAL MONETARY ORDER, SINCE BRETTON WOODS UP TO OUR DAYS. THE ESSAY STARTS BY IMF'S ITINERARY, EMPHASIZING THE 1971 CHANGE IN THE EXCHANGE REGIME PATTERN, FOLLOWS THE DEVELOPMENT OF ITS RELATIONSHIP WITH BRAZIL, THE VARIOUS FORMAL STAND-BY AGREEMENTS CONTRACTED UNDER DIFFERENT ECONOMIC POLICIES, ARISING FROM CURRENT TRANSACTIONS CRISES; A FIRST AGREEMENT WAS ADOPTED IN 1958, AND DISCONTINUED FOR POLITICAL REASONS, BUT THE LAST ONE, CONCLUDED IN 2003, WAS ALSO INTERRUPTED FOR POLITICAL REASONS TWO YEARS LATER. ATTENTION WAS GIVEN TO THE MAIN PROBLEMS FACING THE IMF - EXCHANGE STABILITY, LIQUIDITY, AND THE MONITORING OF THE NATIONAL ECONOMIES - AND TO THE CIRCUMSTANCES THAT FORCED BRAZIL TO ENTER INTO FORMAL AGREEMENTS WITH THE IMF. BRAZIL'S RELATIONSHIP WITH THE IMF WAS SOMEWHAT ERRATIC, WITH PHASES OF ATTRACTION FOLLOWED BY OTHERS OF REPULSION; THERE WAS A COOPERATIVE STANCE - AT THE BEGINNING AND DURING THE WHOLE MILITARY REGIME, AS WELL AS AROUND THE TURN OF THE MILLENNIUM --, ANOTHER CONFRONTATIONAL OR ADVERSARIAL - IN THE KUBITSCHEK GOVERNMENT AND AT THE REDEMOCRATIZATION - TO ARRIVE AT A TRANSFORMATION FROM DEPENDENT BORROWER TO A CREDITOR PUSHING FOR REFORMS IN ORDER TO ENHANCE ITS VOTING RIGHTS IN BOTH BRETTON WOODS INSTITUTIONS; A FINAL TABLE SUMMARIZES THOSE AGREEMENTS AND THE AMOUNTS INVOLVED IN EACH ONE.
\end{abstract}

\section{KEYWORDS}

BRAZIL: IMF; AGREEMENTS; EXCHANGE REGIMES; EXTERNAL DEBT; CURRENT TRANSACTIONS CRISES. 


\section{InTRODUÇÃo: O Brasil E O FMI, DESDE BRETTON WOOdS ${ }^{1}$}

O Brasil é um dos membros fundadores das instituições de Bretton Woods, tendo, aliás, estado na origem das primeiras discussões a respeito da constituição de uma entidade voltada para a estabilização monetária e cambial, feita inicialmente por iniciativa dos Estados Unidos, na conferência extraordinária de chanceleres dos países americanos, realizada no Rio de Janeiro, pouco mais de um mês depois dos ataques japoneses a Pearl Harbor, em janeiro de 1942. O Brasil também recorreu, por vezes de forma intensa, aos serviços e facilidades oferecidos pelas duas instituições de Bretton Woods, o Banco Mundial - para financiar projetos de infraestrutura e desenvolvimento - e o Fundo Monetário Internacional, para enfrentar dificuldades temporárias de balanço de pagamentos, consoante a finalidade precípua do FMI.

O presente ensaio está centrado mais detidamente nas relações mantidas entre o Brasil e FMI, focalizando, por um lado, a origem e a evolução da entidade, examinando, de outro lado, o histórico das operações contraídas pelo País com o Fundo. O Brasil recorreu ao FMI cada vez que enfrentou dificuldades para honrar seus compromissos de pagamentos externos, numa primeira fase dado à baixa dos preços das mercadorias exportadas - como foi o caso com o café no governo Kubitschek, que resultou numa primeira recusa do Brasil em cumprir condicionalidades relativas às contas nacionais e mais frequentemente devido ao acúmulo de obrigações externas em capacidade superior às suas reservas internacionais, em momentos de excesso de investimentos internos - durante os governos militares, por exemplo - ou de mudança nas condições dos mercados financeiros externos (como o aumento das taxas em contratos de juros não fixos, por exemplo) e da própria desvalorização cambial da moeda nacional.

O Brasil sempre relutou em mudar suas políticas domésticas por demanda do FMI, seja porque não queria descontinuar grandes planos de desenvolvimento - mesmo sob o impacto de dois choques externos do petróleo, de que era grande importador nos anos 1970 e início dos 1980 -, seja porque pretendia lidar com programas de estabilização monetária sem se ater às recomendações mais ortodoxas do Fundo - mesmo ao ter de enfrentar surtos inflacionários que redundaram na troca de pelo menos seis padrões monetários, nenhum deles com aprovação prévia ou em coordenação com o FMI. Mesmo na ausência de um aval explícito do Fundo às diferentes tentativas de estabilização macroeconômica empreendidas nos anos 1980 e início dos 1990, o Brasil seguia dependente do Fundo, até, pelo menos, as crises financeiras do final dessa década. A partir daí, não só o Brasil, mas o conjunto de países emergentes deu início a uma fase de acumulação de reservas e de menor dependência de capitais externos, que os colocou temporariamente ao abrigo de novas crises, que, por sua vez, alcançaram países integrantes da União Europeia, por razões basicamente fiscais.

Um resumo da trajetória do relacionamento do Brasil com o FMI, nem sempre isento de conflitos doutrinais e de sucessão de acordos cumpridos pela metade, poderia ser identificado com alguns conceitos típicos de cada fase: o presidente Kubitschek 
deu início à "demonização" do FMI, como sendo uma entidade oposta ao desenvolvimento econômico, apenas interessada na estabilidade monetária, o que marcou profundamente a "psicologia nacional” em relação a esse organismo durante todo o período considerado; o regime militar, por sua vez, manteve, via de regra, boas relações com o FMI, sem dependência numa primeira fase, mas sendo obrigado a negociar sucessivos acordos stand-by em sua fase final, por causa dos choques do petróleo e da crise do endividamento externo, no início dos anos 1980. O Brasil redemocratizado em 1985 manteve más relações com o FMI durante todas as tentativas de estabilização macroeconômica, quando não queria recorrer aos mecanismos clássicos de ajuste, mas tendo de reconhecer sua ampla dependência de capitais estrangeiros, seja com os créditos ou financiamentos oficiais. Nos anos 1990, finalmente, o programa mais bem sucedido de estabilização, o Plano Real, tampouco contou com a aprovação ou o aval do FMI, mas este foi bastante solícito nos pedidos de apoio subsequentes, quando as crises financeiras da Ásia e da Rússia, e depois da Argentina, obrigaram o Brasil a novamente recorrer a créditos do Fundo. O relacionamento se fez em perfeita harmonia nessa fase, embora não se tenha seguido a sugestão inicial do FMI para a desvalorização de sua moeda, o que foi feito, logo em seguida, pelos próprios mercados.

A última grande negociação ocorreu já na transição política para o governo Lula, quando o Brasil contraiu o maior empréstimo, até então, da história do FMI - no valor de US\$ 30 bilhões -, que permitiu, junto com a política prudente mantida no início desse governo, restabelecer a confiança na capacidade de o País honrar compromissos externos. Desde 2005, o Brasil deixou de ser cliente do FMI, tornando-se, ao contrário, um participante ocasional de programas de ajuste para países necessitados e possível financiador da instituição. No âmbito dos BRICS (Brasil, Rússia, Índia, China e África do Sul) decidiu-se, em 2014, a criação de um banco de financiamento de projetos (possível concorrente do Banco Mundial) e de um mecanismo de empréstimos contingentes, complementar aos instrumentos existentes no FMI. Desde o início do milênio, a ação do Brasil nas duas instituições de Bretton Woods vem sendo caracterizada pela tentativa de aumentar sua participação no processo decisório, por meio do crescimento do seu poder de voto mediante a atribuição de maiores cotas (o que vem encontrando resistência de pequenos países europeus, que teriam de ceder participação nesse terreno). As seções a seguir retomam todo esse processo histórico e registram, numa tabela sintética, todos os acordos contraídos pelo Brasil no âmbito do Fundo.

\section{O FMI COMEÇOU No Brasil, DoIs ANOS ANTES DE BRETTON WoOdS...}

O FMI começou no Brasil, dois anos e meio antes de sua criação oficial em Bretton Woods, no New Hampshire, na histórica conferência de julho de 1944, que finalizou 
com a assinatura dos dois convênios constitutivos, um do Fundo Monetário Internacional, outro do Banco Internacional de Reconstrução e Desenvolvimento. A previsão foi feita numa das conclusões da declaração final da terceira conferência dos ministros das relações exteriores das repúblicas americanas, realizada no Rio de Janeiro, em janeiro de 1942, pouco mais de um mês depois do ataque japonês às bases americanas de Pearl Harbor, no Pacífico, em 7 de dezembro de 1941. Na conferência, o representante americano Sumner Welles propôs um projeto de resolução, de apenas cinco linhas, que depois foi incorporado à declaração final, recomendando a criação de um Fundo Internacional de Estabilização, a ser estabelecido pelas Nações Unidas, e associadas, após a conclusão da guerra.

Com efeito, a conclusão XV da Ata Final, tratando do Fundo, começa por estabelecer que a mobilização efetiva dos recursos em divisas pode ser útil na luta contra a depressão e para a realização dos objetivos econômicos que tinham sido acordados na primeira e na segunda conferências, realizadas no Panamá, em 1939, e em Havana, em 1941, e que as repúblicas americanas deveriam

cooperar na criação de uma organização para promover a estabilidade das paridades cambiais, promover os movimentos internacionais de capital produtivo, facilitar a redução de barreiras artificiais e discriminatórias aos fluxos de bens, ajudar na correção da má distribuição de ouro, reforçar os sistemas monetários e ajudar na manutenção de políticas monetárias que evitam graves processos de inflação ou deflação. (FINAL ACT, 1942, p. 25-26)

Em função dessas considerações, a conferência recomendava:

1. Que os governos das repúblicas americanas participem de uma conferência especial de ministros de finanças ou seus representantes a ser convocada com a finalidade de considerar o estabelecimento de um fundo internacional de estabilização.

2. Que a conferência, ao considerar o estabelecimento de tal fundo, formule o esquema de sua organização, poderes e os recursos necessários ao funcionamento adequado do fundo, determine as condições requeridas para a participação no fundo, e proponha princípios para guiar o fundo em suas operações. (FINAL ACT, 1942, p. 26)..$^{2}$

Esta foi apenas uma das resoluções - obviamente não das mais importantes - aprovadas na conferência interamericana extraordinária do Rio de Janeiro, cujo principal resultado foi o rompimento de relações diplomáticas entre os países americanos presentes e as potências do Eixo, com exceção da Argentina e do Chile (ou seja, 19 entre 21 países), que insistiram em se manter neutros, e quase fazem naufragar a conferência de 
solidariedade hemisférica (ARAÚJO, 1996). O Fundo Monetário Internacional criado em Bretton Woods seria bem mais complexo e sofisticado que o Fundo Internacional de Estabilização proposto no Rio de Janeiro, mas é certo que uma organização desse tipo já integrava o planejamento econômico dos estadistas americanos para o pós-guerra.

É também certo que os Estados Unidos de Roosevelt já possuíam, desde 1934, o seu próprio Exchange Stabilization Fund, por meio do qual eles podiam adiantar reservas de crédito a países necessitados contra a garantia das moedas nacionais: mediante acordos de recompra, eles podiam emprestar dólares ao Brasil tomando por prazos curtos valores equivalentes em mil-réis. O economista Edward M. Bernstein, do Tesouro norte-americano e longamente associado ao FMI, tinha defendido a ideia, quando ainda era professor universitário, em seu livro Money and the Economic System (1935); essa proposta de conversão em divisas, em lugar do ouro, depois se tornou uma das mais utilizadas modalidades de operação do Fundo (BLACK, 1991, p. 35).

$\mathrm{Na}$ verdade, Keynes já tinha proposto a emissão de notas garantidas em ouro em seu trabalho The Means to Prosperity (1933), o que foi aproveitado por Harry White, o segundo do Tesouro, para formular sua proposta em um curto memorando, em dezembro de 1941, que depois seria apresentado no Rio de Janeiro, no mês seguinte. A ideia evoluiu no caminho para Bretton Woods - já sob a forma de um fundo, no qual cada país teria uma cota declarada parcialmente em ouro e na sua própria moeda, podendo sacar dessa cota, portanto -, mas ela foi pela primeira vez apresentada ao público, ainda que de forma rudimentar na conferência de ministros do Rio de Janeiro. Sua formulação mais elaborada ocorreu no decorrer de 1942 por meio de um documento intitulado The Treasury's Proposal for an International Stabilization Fund, divulgado quase ao mesmo tempo em que Keynes apresentava o seu plano, baseado no princípio de que os EUA assumiriam praticamente a obrigação de oferecer crédito quase de modo automático aos países deficitários, colocando o peso do ajuste no país credor.

O próximo embate dar-se-ia em Bretton Woods, onde os EUA conseguiram impor suas regras de responsabilidade e de disciplina, contra os objetivos britânicos - ou de Keynes, pessoalmente - de trabalhar, por um lado, com o princípio do bancor (uma moeda contábil, baseada no ouro, a ser utilizada como divisa) e de aceitar, por outro lado, uma união mundial de compensações - International Clearing Union - como mecanismo de ajuste automático entre os países. Em Bretton Woods, como escreve um pesquisador,

[e]m nenhum momento a delegação brasileira pronunciou-se em favor de qualquer dos planos isoladamente, ainda que Eugenio Gudin [um dos membros da delegação chefiada pelo ministro da Fazenda Artur da Souza Costa] tenha admitido posteriormente que se inclinava "pelo de Keynes, porque era mais simples, mais atraente”. Isto contudo não preveniu Souza Costa de adotar o posicionamento presente na proposta keynesiana para 
estabelecer crítica ao retorno do padrão-ouro, visto como um "sistema rígido de paridades [que] subordina a economia interna à taxa cambial”. (BARREIROS, 2009, p. 533-534).

De certo modo, o plano White parecia, ao chefe da delegação brasileira, mais consentâneo com o controle dos ativos, na medida em que o de Keynes era mais expansionista, ao passo que o primeiro subordinava a expansão do crédito ao depósito de reservas. Ao mesmo tempo, o sistema de compensações proposto por Keynes parecia-lhe mais engenhoso, uma vez que justamente poupava um País de ter de apelar imediatamente para as suas reservas (BARREIROS, 2009, p. 537-538). Na verdade, a delegação brasileira estava bem mais interessada em mecanismos de regularização da oferta e da estabilização dos preços das matérias-primas, uma vez que da exportação de várias delas dependia o essencial das receitas em divisas do País. "A delegação brasileira propôs uma conferência específica para promover a estabilidade nos preços dos produtos de base, ideia que seria retomada na Conferência das Nações Unidas sobre Comércio e Emprego em Havana e em diversas reuniões econômicas que, nos anos 50 e começo dos 60, levam à constituição da Conferência das Nações Unidas sobre Comércio e Desenvolvimento (UNCTAD).” (ALMEIDA, 2012, p. 132)

Ao final, nem o bancor, nem a Clearing Union foram implementados, como Keynes pretendia, embora os ingleses tenham obtido empréstimos generosos dos EUA, que, aliás, não protestaram além da conta quando a libra foi desvalorizada à margem das regras do FMI, numa fase (segunda metade dos anos 1940) em que também a França agiu do mesmo modo, ambos em meio a uma difícil situação de déficits imensos, tendo ainda de enfrentar a chamada "penúria de dólares". Naquela fase, além das cotas, claramente insuficientes e ainda não operacionais, os países não podiam contar muito com a ajuda do Banco Mundial, também constrangido pela escassez de recursos em seus primeiros anos. Nessa primeira fase, a política econômica relativamente ortodoxa conduzida no Brasil pelos ministros do governo Eurico Dutra coincide com a filosofia imperante no FMI. Sem embargo, a saída de capitais e o esgotamento das reservas em divisas acumuladas durante a guerra - processo também acelerado pela liberalização das importações como meio de controlar a inflação - atingem tais proporções que o governo é obrigado a reintroduzir medidas de controle cambial em meados de 1947 (BERGSMAN, 1970, p. 27-54 e 1977, p. 391-410; HUDDLE, 1977, p. 357-384).

Uma das etapas mais significativas do relacionamento do Brasil com o FMI, nos primeiros anos, é representada pelo rompimento, em 1959, por Juscelino Kubitschek, de um acordo stand-by negociado no ano anterior pelo seu ministro Lucas Lopes. Esse gesto de fundo essencialmente político e quase demagógico assumiu, na simbologia de uma história simplista, ares de declaração triunfalista de independência econômica por parte do Brasil, como se o FMI e, por trás dele, o governo dos Estados Unidos tivessem interesse em colonizar ou humilhar o País, quando o que estava em jogo era 
tão somente o cumprimento de certos critérios de desempenho em matéria monetária e fiscal (VIANNA, 1989, p. 132-34). Na verdade, Kubitschek, já comprometido com o projeto de construção de Brasília pela via fácil (e altamente irresponsável) das emissões inflacionistas, não pretendia submeter-se a nenhum tipo de controle de gastos (menos ainda de elaboração orçamentária normal). O fato é que as "explicações" dadas por JK para justificar o rompimento do acordo stand-by com o Fundo o atendimento das exigências teria redundado, por exemplo, no "aniquilamento" do País, ele teria de "abrir mão do Plano de Metas" e deixaria o povo "passando fome" passaram a integrar a demonologia da esquerda brasileira em relação ao FMI - logo identificado com "fome e miséria internacional" - e que continuou durante anos a fio, constituindo um caso exemplar de autoengano coletivo cultivado de maneira persistente durante as décadas seguintes (IANNI, 1971, passim).

\section{OS DIREITOS ESPECIAIS DE SAQUE TAMBÉM COMEÇARAM NO BRASIL}

Uma solução parcial ao problema da liquidez no sistema monetário internacional surgiria anos mais tarde, com as primeiras fissuras já evidentes no edifício construído em Bretton Woods, e ela está também formalmente identificada com o Brasil: a criação dos Direitos Especiais de Saque, SDR na sigla em inglês (Special Drawing Rights). Eles foram adotados na única conferência que o FMI fez no Brasil, mais exatamente no Rio de Janeiro, em setembro de 1967, depois de muita discussão sobre como equacionar dificuldades associadas aos desequilíbrios econômicos de alguns grandes parceiros do sistema de pagamentos internacionais, problemas agravados desde o restabelecimento da convertibilidade das moedas dos países europeus e do Japão, no final dos anos 1950 e início dos anos 1960 (CONNELL, 2013, p. 18).

A partir de 1958, os países europeus começaram a converter seus ativos em dólares contra lingotes de ouro depositados em Fort Knox. Como indicou Edward Bernstein, "[b]y 1963, the drain of gold from our reserves had become enormous. In the preceding five years, U.S. gold reserves fell by a one-third, and more than half of Europe's reserves was in the form of gold, with the rest mainly in official holdings of dollars" (BLACK, 1991, p. 83). A verdade é que as reservas metálicas dos EUA passaram a representar uma parte crescentemente menor da expansão de crédito conduzida pelo seu governo durante todo o período de funcionamento oficial do sistema de Bretton Woods.

Vários economistas já tinham, por essa época, detectado a natureza dos desequilíbrios e propunham diferentes soluções para os problemas identificados, não necessariamente concordantes quanto à natureza do remédio a ser introduzido. Os problemas eram basicamente de três ordens: (a) oferta de liquidez, como requerida por um sistema de taxas estáveis a partir do crescimento contínuo dos fluxos internacionais de comércio de bens e serviços; (b) confiança, dependente das medidas tomadas pelos principais parceiros, no sentido de empreender ajustes ou efetuar desvalorizações de 
suas moedas; (c) programas de ajustes, que deveriam necessariamente ser feitos nos casos de desequilíbrios de balanço de pagamentos, que normalmente estão associados a processos inflacionários persistentes ou severos (CONNELL, 2013, p. 42).

Robert Triffin, por exemplo, depois de sugerir, precocemente, uma organização coletiva em torno da internacionalização efetiva do sistema de câmbio-ouro, passou a se inclinar por uma espécie de banco central internacional, encarregado de administrar os processos de ajuste $(1957 ; 1960)$. Bernstein (1960) concebeu desde essa época a criação de um Reserve Settlement Account, com ouro, dólar e um novo ativo podendo servir como moeda de reserva. Pouco depois, em 1963, era constituído um grupo de trabalho, sob a liderança do economista Fritz Machlup, de Robert Triffin e de William Fellner, conhecido como Grupo de Bellagio - do nome da localidade italiana onde ele se reuniu pela primeira vez - que se ocupou, nos três anos seguintes, de formular novas sugestões aos desequilíbrios crescentes (CONNELL, 2013, p. 19-20). ${ }^{3}$ Nessa época, o general De Gaulle, e seu conselheiro econômico Jacques Rueff (que tinha estado na reforma monetária de 1928, que levou a França de volta ao padrão ouro, mas com uma desvalorização significativa), dedicavam-se a converter suas reservas em dólar em lingotes de ouro depositados em Fort Knox. Quando outros países, que também detinham reservas de centenas de milhões em dólares, tentaram fazer o mesmo, como Alemanha e Japão, por exemplo, mas que eram dependentes obrigatórios do guarda-chuva militar americano, eles foram gentilmente convidados a guardar os seus dólares, sob a justificativa - expressamente declarada por um secretário do Tesouro norte-americano de que o dollar [was] as good as gold.

Mas, na segunda metade dos anos 1960, o ouro já não podia exercer sua função de prover liquidez ao sistema monetário, dadas as contradições inevitáveis derivadas de seu papel de commodity com múltiplos objetivos não monetários (no sistema industrial, para entesouramento, decoração, especulação etc.) ademais dos problemas políticos derivados de serem seus principais supridores a África do Sul do Apartheid e a União Soviética de decisões impenetráveis e totalmente à margem da ordem criada em Bretton Woods (de cuja conferência ela participou, mas se mantendo ausente desde a origem). De toda forma a oferta anual de ouro parecia ser inadequada e errática para irrigar o sistema de maneira conveniente, ademais dos problemas causados pelo desalinhamento entre o seu preço oficial como instrumento monetário e de referência de paridade e suas flutuações de valor como mercadoria de múltiplas utilizações.

Dez anos passaram-se entre a identificação precoce do problema da liquidez por Robert Triffin e a adoção final do mecanismo dos Direitos Especiais de Saque (SDR), em 1970, mas a decisão já tinha sido adotada na reunião do FMI no Rio de Janeiro, em 1967 (KRAUZE, 1971, p. 21-22). Edward Bernstein havia sugerido, anteriormente, que a nova ferramenta seria chamada simplesmente de Reserve Unit, mas devido à oposição obstinada dos franceses (o Secretário do Trésor, Valéry Giscard D’Estaing, que se tornou presidente), o nome escolhido foi Droits de Tirage Spéciaux (Special 
Drawing Rights). A razão dessa diferença terminológica também se prendia a concepções diversas dos dois mecanismos: os europeus preferiam "direitos de saque”, que estavam ligados a obrigações de crédito, em lugar de uma unidade de reserva, que poderia ser considerada uma nova moeda ou um substituto para o ouro (CONNELL, 2013, p. 129).

A partir de 1963, quando o FMI estabelece o Grupo dos Dez - na verdade, os vice-ministros dos dez países integrantes dos General Arrangements to Borrow, criados em 1962, para expandir os seus recursos - bem como um grupo de estudo para tratar de uma possível reforma monetária, um outro grupo de economistas acadêmicos, mas independentes dos governos e do próprio Fundo -, reúnem-se em Bellagio para também formular suas sugestões de reforma, com a peculiaridade que, à diferença dos representantes de governos e dos burocratas internacionais, eles podiam especular sobre os diferentes cenários que proposições diversas, e até conflitantes, teriam sobre os fluxos reais de comércio, finanças e investimentos no plano mundial. Sob a liderança de Fritz Machlup, os economistas interagem com o Grupo dos Dez e com o grupo de estudos do FMI, com vistas a ajustar suas diferentes visões da reforma do sistema monetário internacional.

Finalmente, como resultado de um esforço de vários anos, o relatório de trabalho dos vice-ministros do Grupo dos Dez é aprovado na assembleia anual do FMI, no Rio de Janeiro, em setembro de 1967, sugerindo a criação dos SDRs. Ainda demoraria dois anos mais para que a mudança do convênio constitutivo do FMI fosse efetuada; em 1970, finalmente, ocorre a primeira criação e alocação de SDRs, num montante pouco inferior a 9,3 bilhões de unidades. Dez anos depois, os montantes globais da nova reserva monetária, inicialmente baseada num coquetel de moedas integrado, em montantes proporcionais, pelas divisas dos 16 mais importantes exportadores mundiais, já tinham sido mais que duplicados, chegando a representar cerca de 5\% das reservas monetárias (não metálicas) mundiais (HAZLITT, 1984, p. 16). ${ }^{4}$

Nessa época, o Brasil do regime militar, estava em bem melhores termos com o FMI do que tinha sido nos governos JK e João Goulart, de que são exemplos os sucessivos acordos stand-by negociados praticamente ano a ano entre 1965 e 1972 (PEREIRA, 1974, p. 49; CRUZ, 1984, passim). De fato, esses acordos não eram necessários do ponto de vista estrito da balança de pagamentos, justificando-se apenas como uma espécie de "selo de qualidade" das políticas econômicas implementadas nessa fase de estabilização. Dos quase 570 milhões de Direitos Especiais de Saque (DES) concedidos nessa época em oito operações anuais, o Brasil sacou apenas 150 milhões (em duas fatias de 75 milhões cada, as primeiras, sem condicionalidades), contentando-se o governo com o aval do FMI para fins de renegociação da dívida com credores oficiais. O BIRD, a partir dessa época, também passou a emprestar com maior liberalidade ao Brasil, assim como a AID, a agência oficial de ajuda ao desenvolvimento do governo dos Estados Unidos, ou o Eximbank (OLIVEIRA, 1993, p. 78). 
Ainda assim, não havia um perfeito entendimento entre o Brasil e o FMI a respeito das principais políticas a serem adotadas pelo Brasil para compatibilizar estabilização e crescimento. Como confirmou um dos principais formuladores econômicos, à época ministro do planejamento Roberto Campos: "O Fundo Monetário Internacional não aceitava o gradualismo. Sugeria um tratamento de choque. Nós argumentávamos que o tratamento de choque era impraticável e que os modelos europeus de cura súbita da inflação não eram aplicáveis ao caso brasileiro...” (BIDERMAN, 1996, p. 49).

Essa fase também assistiu ao início do chamado "milagre econômico brasileiro", entre 1967 e a primeira crise do petróleo, em 1973, coincidindo com o ingresso de importantes fluxos de investimento estrangeiro, tendo o governo atuado inclusive no sentido de restringir o excesso de entradas, de maneira a não provocar surtos inflacionários na economia nacional. Mesmo depois do início de problemas na balança de pagamentos, com a triplicação dos preços do petróleo e a continuidade das grandes obras de infraestrutura, e dos investimentos estatais patrocinados pelo governo "desenvolvimentista” de Geisel, o governo evitou fazer apelo ao FMI, preferindo pedir socorro nos euromercados, então regurgitando de petrodólares que passaram a ser reciclados em condições extremamente generosas para com os tomadores (taxas de juros praticamente negativas, em face da aceleração da inflação nos países centrais). De resto, o FMI teve papel pouco ativo na fase de grandes turbulências dos anos 1970, atingido ele mesmo pela alteração quase completa dos fundamentos que tinham presidido sua atuação institucional desde a assinatura dos acordos de Bretton Woods: o regime de paridades fixas e a conversibilidade do dólar em ouro a uma taxa estável (ALMEIDA, 2002; 2003, passim).

\section{OS DeSEquilíbrios ACUMULAM-SE E Nixon CORTA O NÓ GÓRDIO DE BRETTON WOODS}

$\mathrm{Na}$ verdade, a nova liquidez criada pelos SDRs resolvia apenas parcialmente um dos muitos problemas do sistema monetário internacional, faltando tratar do problema quase intratável da fixação, ou da alteração, das paridades cambiais. Os principais parceiros sempre se preocuparam com a questão fundamental de quem, finalmente, suportaria os custos do ajuste, ou da desvalorização. O fato é que, desde o início da entrada em vigor do sistema de Bretton Woods e, sobretudo, no decorrer dos anos 1960, o dólar suportou mais desvalorizações que valorizações de outras moedas, ${ }^{5}$ mesmo em face de uma constante, ainda que irregular, perda de competitividade externa dos EUA. Mas os Estados Unidos, segundo os acordos de Bretton Woods, não podia facilmente desvalorizar a sua própria moeda, vinculada ao ouro desde a origem, inclusive porque o valor de US\$ 35 por onça de ouro estava fixado na legislação aprovada pelo Congresso (KRAUZE, 1971, p. 31). 
A deterioração progressiva da posição externa dos EUA nos anos 1960 - em grande medida o resultado de seus próprios desequilíbrios internos, com a elevação concomitante da inflação - tornou-se o principal assunto de política monetária da administração Nixon, e que também representou um grande problema para o sistema financeiro internacional. Bem antes da decisão dramática, adotada em agosto de 1971, muitos especialistas já vinham discutindo a hipótese da flexibilização das paridades cambiais, a exemplo de Milton Friedman, que, em 1952, inaugurou o debate com seu artigo sobre as taxas de câmbio flexíveis (FRIEDMAN, 1953). Na raiz de todos esses problemas sempre se encontra a tensão reincidente entre as forças incontroláveis dos mercados e a vontade dos governos de preservar soberania sobre certos aspectos de suas políticas econômicas. Como argumentou um observador contemporâneo da decisão adotada em agosto de 1971, "É totalmente impossível manter um mercado aberto, do qual depende a prosperidade, e, ao mesmo tempo, ter governos exercendo orientação intrusiva e detalhada sobre as economias individualmente" (KRAUZE, 1971, p. 49). Antes mesmo de consumada a decisão finalmente anunciada, unilateralmente, pelo presidente Nixon, naquela data, muitos economistas acadêmicos, nas melhores universidades americanas, vinham preconizando justamente a adoção de um regime flexível para o câmbio. ${ }^{6}$

\section{OS CHOQUES DO PETRÓlEO E A CRISE DA DÍVIDA LATINO-AMERICANA DOS ANOS I980}

Uma nova crise do petróleo, em 1979, agravou a situação das transações correntes do Brasil, numa fase em que as taxas de juros passam a ser flutuantes e de fato aumentam extraordinariamente, a partir da política do Federal Reserve de verdadeiramente combater a inflação nos Estados Unidos. O governo Figueiredo, com Delfim Netto à frente da economia, hesitou, entretanto, em recorrer ao FMI, na medida em que o apelo teria um enorme custo político. Ele só o fez quando a situação já tinha saído de controle, com escassez de capitais voluntários a partir da guerra das Malvinas (maio de 1982) e, sobretudo, com o deslanchar da moratória mexicana em agosto desse ano (ALMEIDA, 2005, p. 245).

A partir do segundo semestre de 1982, começando pelo México, uma onda de inadimplências se abateu sobre vários países latino-americanos, o que levaria a uma virtual paralisação do sistema de créditos comerciais se o diretor-gerente do FMI, nessa época o francês Jacques de Larosière, não obrigasse os bancos comerciais a continuarem emprestando para os mesmos países, sobre a base de renegociações de suas obrigações de pagamentos de amortizações devidas. O Grupo dos Dez prometeu triplicar seus recursos para empréstimos entre os bancos centrais, e o próprio FMI considerou aumentar em 50\% seus recursos para empréstimos, colocando-os na faixa inédita, até então, de US\$ 90 bilhões (The New York Times, 18 jan. 1983). Nessa fase, 
o Brasil tornou-se o principal país endividado num grupo que compreendia o México, a Argentina e a Venezuela, com uma grande cobertura oferecida pelos bancos comerciais americanos, como se pode verificar na tabela abaixo.

tabela 1 - DÍVIdA de PAÍ́SES LATINO-AMERICANOS, I983 (US\$ BILHÕes)

PAÍSES

\begin{tabular}{rll}
\hline BRASIL & 86,3 & 22,0 \\
\hline MÉXICO & 84,6 & 24,3 \\
\hline ARGENTINA & 36,5 & 8,6 \\
\hline VENEZUELA & 32,6 & 11,2 \\
\hline CHILE & 17,2 & 5,9 \\
\hline PERU & 11,6 & 2,4 \\
\hline EQLÔMBIA & 10,5 & 3,7 \\
\hline
\end{tabular}

Fonte: Morgan Guaranty Trust Company (The New York Times, 5 set. 1983).

Entre o início de 1983 - quando um acordo dito EFF (Extended Fund Facility) é negociado - e o final do regime militar, o Brasil beneficiou-se de créditos emergenciais do Fundo, mas não conseguiu cumprir a maior parte das exigências e requerimentos formulados pelo staff do órgão e estabelecidos por sua diretoria, pois que não obtinha condições políticas para um conjunto de reformas tendentes a desindexar a economia brasileira e a colocar as contas públicas sob controle. O ministro Delfim Netto negociou e renegociou "meia dúzia" de cartas de intenções para sustentar um acordo stand-by que nunca foi implementado em forma integral. A estrutura dos empréstimos consorciados, envolvendo dezenas, senão centenas de bancos - os chamados syndicated loans - era obviamente uma dificuldade: um comitê assessor dos bancos credores foi rapidamente constituído, mas seu funcionamento deixava bastante a desejar em face das disputas entre os próprios bancos para um tratamento preferencial para os seus créditos (CERQUEIRA, 1997, p. 16, 35-36).

A inadequação dos mecanismos institucionais para o encaminhamento adequado do problema da dívida externa era patente. Por um lado, os bancos privados tinham sido extremamente irresponsáveis ao conceder empréstimos sobre empréstimos aos 
governos dos países em desenvolvimento, na suposição absurdamente anti-histórica de que Estados soberanos não vão à bancarrota e não declaram moratória. Eles estavam esperando que o governo dos Estados Unidos e o próprio FMI garantissem pelo menos o pagamento dos juros por parte dos países devedores, algo que esteve sob risco em diversas ocasiões. Por outro lado, o FMI estava apenas equipado para tratar de desequilíbrios temporários de balanço de pagamentos, não para administrar um processo prolongado de renegociação de dívidas soberanas e comerciais.

A descoordenação política e operacional em torno do problema da dívida externa era, de fato, muito grande, envolvendo muitos atores: FMI, Banco Mundial, Tesouro americano, Federal Reserve, Departamento de Estado, agências garantidoras de créditos comerciais, outros governos credores - geralmente europeus, mas também os japoneses e canadenses - ademais, obviamente, dos bancos privados, centenas deles, a começar pelos grandes de Wall Street e da City londrina. Um certo grau de energia por parte dos funcionários americanos e também um pouco de sorte - assim como a própria cooperação dos principais devedores, a começar pelo México e pelo Brasil - evitou o pior: o colapso do sistema financeiro internacional. O esquema não evitou, contudo, a estagnação e a crise nesses mesmos países, dando origem ao estigma da "década perdida”. Oportunamente, a introdução do princípio do reescalonamento com desconto do valor face - ou fixação de juros -, como consubstanciado no Plano Baker, permitiu a lenta reabsorção dos casos mais graves de inadimplência financeira, com perdas desigualmente distribuídas entre os credores e os tomadores (GAROFALO, 2002, p. 159).

Entretempos, no Brasil, a condução do processo de entendimentos com o Fundo foi bastante errática e irregular: logo depois do descumprimento das metas acertadas no acordo de facilidades ampliadas (EFF) do início de 1983, nova missão do FMI veio ao Brasil para tentar convencer as autoridades brasileiras a desindexar a correção automática dos salários, além, obviamente. de estabelecer metas precisas para a redução da inflação. Como relatado em uma história oficial do FMI cobrindo esse período, "Os brasileiros tinham resistência a esse tipo de requisito e o seu duradouro e altamente influente diretor executivo, Alexandre Kafka, reclamou que esse nível de envolvimento estrutural na política econômica era pouco apropriado e não tinha precedentes." (BOUGHTON, 2001, p. 373)

A partir daí - e a despeito de renegociações conduzidas no âmbito do Clube de Paris -, os desencontros entre o Brasil e a comunidade de credores oficiais e privados foram frequentes, atravessando, inclusive, a mudança de regime político do início de 1985, até culminar na famosa moratória de 1987, quando, pela primeira vez em muitas décadas, o País declarou a impossibilidade de continuar honrando seus compromissos externos. Não obstante as grandes transformações econômicas ocorridas durante o regime militar, e também na fase de redemocratização, o lado da inserção financeira externa foi sempre mais errático que o processo de fortalecimento do sistema produtivo. 
O lado financeiro esteve submetido a fluxos e refluxos, alimentados tanto pela conjuntura internacional como pela situação específica da economia, submetida a conhecidos impulsos inflacionários e a desequilíbrios temporários, alguns derivados de problemas sistêmicos e crônicos - como gargalos produtivos e insuficiência de recursos -, outros decorrentes de arranjos institucionais, que também podiam, eventualmente, converter-se em questões estruturais ou sistêmicas (MONTEIRO, 2004, passim).

\section{Encontros e desencontros entre o Brasil E O FMI NAS DUAS DÉCADAS PERDIDAS}

Em janeiro de 1985, como forma de pressionar por novas facilidades creditícias, o governo brasileiro anunciou que estaria suspendendo o pagamento de juros sobre a dívida oficial bilateral até o reescalonamento dessas dívidas, ao que o Clube de Paris respondeu que o estabelecimento de um acordo stand-by com o FMI era a condição necessária para fazê-lo. A substituição de Francisco Dornelles por Dilson Funaro, em meados daquele ano, não foi particularmente bem-sucedida em termos de entendimentos com o FMI e com os demais credores oficiais e privados. A "novela da dívida" e o "balé de missões" do Fundo ao Brasil continuaram pelos meses seguintes, sem qualquer progresso substantivo na condução das renegociações e com muito pouco progresso no tratamento conceitual do problema. O presidente Sarney adotou uma retórica anti-Fundo, ao declarar em setembro de 1986 - e descartando o simples fato de que o Brasil não cumpria nenhum plano com a instituição - que "as fórmulas do FMI para o Brasil simplesmente não funcionam. Elas nos conduziram à mais dramática recessão em toda nossa história.” (BOUGHTON, 2001, p. 455)

A moratória declarada em fevereiro de 1987, envolvendo o pagamento de juros dos empréstimos de médio e longo prazo dos credores privados, chocou o mundo e o FMI, mas de fato ela era inevitável: a dívida total era então de 121 bilhões de dólares e as reservas brutas tinham caído dramaticamente de US\$ 9,25 bilhões no final de 1985 para menos de 4 bilhões no momento da moratória (PORTELLA FILHO, 1988). Uma renegociação inédita - isto é, sem o aval do Fundo e sem um stand-by em vigor - tinha, no entanto, sido concluída com o Clube de Paris um mês antes, o que permitiu algumas acomodações até que o ministro Funaro fosse substituído por Luiz Carlos Bresser Pereira, em abril de 1987 (BATISTA JR., 1988, passim).

O novo ministro não pretendia renegociar com o Fundo antes de acomodar a situação com os banqueiros privados, aos quais pediu um novo empréstimo-ponte a uma taxa de juros zero: levou zero empréstimo. Seu plano de debt relief para o Brasil - de fato de "securitização" da dívida -, discutido com funcionários do Tesouro norte-americano, foi recebido com um non-starter, a começar pelo próprio secretário do Tesouro James Baker, que recusou em setembro daquele ano desvincular o esquema "voluntário" de redução de dívidas privadas dos arranjos com o FMI (PEREIRA, 1988; 1989). O mais 
extraordinário é que esse esquema conceitual veio depois a ser consubstanciado no chamado Plano Brady, nome do sucessor de Baker à frente do Tesouro. O episódio revela, em todo caso, que o crédito político e financeiro do Brasil estava próximo de zero e, provavelmente, com poucas perspectivas de melhoria (CERQUEIRA, 1997, passim; BAER, 1989, p. 184-218).

Esse tipo de guerrilha financeira sem vitórias nem vencedores continuaria pelo resto da década, até que a gestão Marcílio Marques Moreira, na Fazenda, no princípio dos anos 1990, seguida mais adiante pela de Fernando Henrique Cardoso na mesma pasta - com Pedro Malan designado como negociador oficial da dívida externa - permitiu dar início a uma nova fase no relacionamento do Brasil com a comunidade financeira internacional (MOREIRA, 2001, p. 163-83, esp. 174-177). Um pouco antes dessa época, o Fundo e as próprias autoridades americanas já estavam convencidos que era preciso separar a estratégia do tratamento da dívida dos interesses dos banqueiros privados, o que foi logrado em 1989 por meio do Plano Brady, que previa precisamente uma estratégia mais flexível para o debt relief, e para o apoio do FMI aos novos esquemas de facilitação da renegociação dos créditos oficiais e dos empréstimos privados (CERQUEIRA, 1997, p. 59-60; MEYER, 1992, p. 51-90).

No intervalo, o sucessor de Bresser na Fazenda, Mailson Ferreira da Nóbrega, assinou uma carta de intenções com o Fundo, em junho de 1988, prevendo a negociação de um novo acordo stand-by e antecipando negociações com banqueiros e o Clube de Paris. Em agosto, o Brasil conseguiu sacar uma tranche de 365 milhões de DES (Direito Especial de Saque) de um total de mais de 1 bilhão aprovados, mas isso foi tudo. As turbulências políticas do final do governo Sarney e as expectativas geradas pela nova Constituição, entretanto, minaram os esforços do ministro Mailson em prol de acordos consistentes e duráveis com aqueles parceiros. Da mesma forma, uma carta de intenções negociada em setembro de 1990, já no governo Collor, não teve implementação em virtude das demais inconsistências do plano de estabilização introduzido em março daquele ano. Mas, o ministro Marcílio Marques Moreira logrou concretizar um reescalonamento no âmbito do Clube de Paris em 1992, mesmo sem dispor do aval do FMI.

Com a presença de Fernando Henrique Cardoso na condução dos negócios da Fazenda, a partir de maio de 1993, e uma brilhante equipe de assessores econômicos em postos estratégicos do governo Itamar Franco, foi possível conduzir, pela primeira vez em muitos anos, um processo realista e consistente de ajuste estrutural que, via desindexação planejada da economia, acabaria levando ao plano Real, passando pela solução parcial do problema da dívida em abril de 1994 e a subsequente suspensão oficial da moratória. Um acordo com o Clube de Paris em 1992 tinha contornado a situação dos créditos oficiais, reconduzidos por um período suplementar de pagamentos comprometidos.

O primeiro governo Fernando Henrique Cardoso, eleito em outubro de 1994, em virtude basicamente do sucesso do Plano Real, inicia, em 1995, sua gestão com 
um desafio externo de grande amplitude: controlar os efeitos da crise do México de dezembro daquele ano e garantir a manutenção da estabilidade cambial, o que foi obtido mediante pequeno ajuste na política de valorização cambial do período inicial do programa de estabilização (CERQUEIRA, 1997, p. 62-64). Introduziu-se o sistema de bandas e a prática de correções ou ajustes ("minidesvalorizações" disfarçadas) dentro da banda, de maneira a compensar parte da erosão inflacionária e a valorização de fato pela qual passou o Real a partir de sua introdução nos segundo semestre de 1994. No plano internacional, o governo FHC começa a propor, mediante carta do presidente aos países do G-7, medidas de controle dos capitais voláteis, sem muita receptividade, porém.

Ao mesmo tempo, entretanto, o G-7 também propunha a liberalização dos movimentos de capitais, área que nunca fez parte da jurisdição do FMI, consoante o espírito keynesiano que presidiu aos acordos de Bretton Woods, voltados basicamente para a liberalização dos pagamentos correntes (à exclusão, portanto, dos fluxos voluntários de ativos). As autoridades monetárias brasileiras, a despeito de uma adesão conceitual ao princípio da liberalização progressiva e cautelosa desses fluxos, não concordavam com a ideia de abandonar de vez o monitoramento nacional desses capitais, uma vez que, escolado pelos desequilíbrios persistentes que o País conheceu praticamente desde a inauguração da República, o Brasil sequer tinha operado, quando da ratificação dos acordos de Bretton Woods, a liberalização completa de seus pagamentos correntes (fazendo uso das exceções previstas no artigo 14 do convênio constitutivo do FMI, para derrogar às obrigações previstas no artigo $8^{\circ}$, aceito integralmente apenas numa fase ulterior).

O ministro da Fazenda, Pedro Malan, também expressou restrições ao caráter amplo do sistema de disseminação de dados, argumentando que sua divulgação poderia ser fator de instabilidade, em lugar de contribuir para a estabilização dos mercados financeiros. Em todo caso, consoante seu novo papel internacional e de liderança na diplomacia dos países em desenvolvimento mais dinâmicos, o Brasil foi convidado em 1996, junto com outros sete países emergentes, a ingressar no Banco de Compensações Internacionais (BIS, na sua sigla em inglês), o que foi efetivado em 1997, assim como a participar, mais tarde, de esquemas restritos de discussão das turbulências financeiras (como o G-20).

\section{As CRISES ASIÁtICAS E A MORATÓRIA RUSSA: O BRASIL VOLTA AO FMI}

Começando pelo México em 1994-1995, continuando na Ásia dois anos depois, estendendo-se à Rússia em agosto de 1998 e, logo em seguida, ao Brasil, uma série de crises financeiras abalou o sistema internacional. Elas não foram as primeiras, nem serão as últimas de uma série que Charles Kindleberger chamou de "manias, pânicos e colapsos" do capitalismo (1978). Os mercados geralmente funcionam, mas eles podem enfrentar rupturas, o que requer intervenção governamental para prover estabilidade. O dilema é que se os mercados sabem que alguma ajuda virá, eles vão quebrar mais frequentemente 
e funcionar de maneira menos eficiente. Este é o debate atual em torno do chamado moral hazard, comportamento de risco dada a existência de um "salvador".

Quando a crise financeira internacional atingiu igualmente o Brasil, no seguimento da moratória russa de agosto de 1998, e ameaçou propagar-se a outros países emergentes, o sistema internacional ficou ele próprio sob risco de colapso, o que levou às reuniões de emergência das autoridades do G-7 e do FMI (BLUSTEIN, 2001). Um pacote de ajuste fiscal, prevendo redução de gastos da administração em proporção equivalente a 2,5\% do PIB e estritamente monitorado pela instituição, foi a condição essencial para se lograr uma ajuda financeira do FMI e de países-membros do G-7 e do BIS.

Essa ajuda inaugurou uma nova modalidade de intervenção das instituições financeiras internacionais, já que se tratava de disponibilizar recursos para reforçar as reservas internacionais do Brasil em caráter preventivo, ou seja, antes que se manifestasse uma inadimplência de fato, seguida de eventual decretação de moratória, como tinha sido o caso anterior da Rússia. Ela antecipou a utilização da chamada Supplemental Reserve Facility (SRF), instrumento de crédito inovador, pois que destinado justamente a evitar a sustentação pós-crise dos desajustes de balanço de pagamentos.

A montagem de um esquema de sustentação financeira em favor do Brasil tornou-se inevitável quando, no bojo das crises asiática e russa, os capitais de empréstimo e de crédito comercial tornaram-se repentinamente escassos, operando-se, ao contrário, uma retirada em massa de volumes consideráveis de recursos antes aplicados de forma voluntária na economia brasileira. As reservas nacionais começaram a diminuir de forma dramática, de algo como 72 bilhões no período anterior à crise russa para menos de 40 bilhões em meados de novembro de 1998. A dependência financeira do Brasil ficou evidenciada a partir de 1996, quando o déficit nas transações correntes atingiu cerca de 3,27\% do PIB, de um patamar relativamente confortável de aproximadamente 0,3\% no começo do Plano Real. Em novembro de 1998, o déficit acumulado em 12 meses já atingia 34 bilhões de dólares, ou seja, 4,43\% do PIB, colocando em relevo a necessidade de um aporte suplementar de recursos institucionais, adicionalmente ao volume de investimentos diretos e de aportes por motivo de privatizações (que em 1998 atingiram, de forma conjunta, um volume recorde de 24,5 bilhões de dólares).

O pacote de ajuda, anunciado finalmente em 13 de novembro de 1998, tinha sido montado em plena assembleia anual das instituições de Bretton Woods, no mês de outubro, e complementado por contatos diretos das autoridades financeiras do Brasil com seus parceiros das principais economias desenvolvidas e com funcionários do FMI: ele consistia em um crédito stand-by de 18 bilhões de dólares do Fundo, mais o uso das Supplemental Reserve Facilities por um prazo de 36 meses. Ademais 9 bilhões de dólares das instituições multilaterais de crédito (BIRD e BID), o Brasil habilitou-se a receber cerca de 20 bilhões de dólares no espaço de três meses a partir de novembro 
de 1998 e até 32 bilhões no prazo de um ano, do FMI e de membros do BIS, dependendo do nível de suas reservas internacionais e do grau de implementação do pacote de ajuste fiscal.

Em contrapartida, o Brasil comprometeu-se a manter reservas cambiais à altura de 25 bilhões de dólares, uma firme disciplina monetária (com superávits primários equivalentes a 1,8\% do PIB em 1999, 2\% em 2000 e 2,3\% em 2001, segundo o memorando de entendimento então firmado), mas preservou os fundamentos de sua política cambial, baseada num regime flexível de desvalorizações internas a uma banda de flutuação administrada pelo Banco Central. Esse regime cambial seria, em janeiro de 1999, radicalmente alterado em sua forma de funcionamento, no decorrer da crise sucessiva do modelo implantado em julho de 1994 e ligeiramente ajustado em abril de 1995, adotando-se a partir de então um regime de flutuação que se revelou relativamente satisfatório.

O caráter original do pacote de apoio financeiro das instituições internacionais e do grupo de 20 países que dele fizeram parte situou-se na sua natureza híbrida, concebido parcialmente como acordo stand-by clássico e, de maneira inédita, parcialmente como um instrumento de tipo preventivo, podendo ser acionado sem as condicionalidades normalmente associadas a esse tipo de acordo. Em outros termos, parte dos recursos foi liberada para integrar as reservas do Brasil, independentemente da necessidade de cobertura de obrigações cambiais imediatas. Outras características inovadoras foram o maior custo de uma parte do dinheiro disponibilizado - em relação às taxas normalmente praticadas pelo FMI -, exigência vinculada às condições sob as quais o Congresso dos Estados Unidos aprovou o pacote de recursos adicionais para a recomposição do capital do FMI e para a integralização dos New Arrangements to Borrow, estes adicionais aos recursos providos sob o "velho" esquema dos General Arrangements to Borrow (GAB, isto é, acordos gerais de empréstimos entre bancos centrais), administrado geralmente no quadro do BIS.

\section{A CRise ARgentina e CENÁRio Eleitoral DE 2002:}

\section{AS NOVAS FASES DO DRAMA}

A recuperação econômica, na esteira da desvalorização, foi bem-sucedida e, em abril de 2000, o Banco Central anunciou a queda dos juros e o pagamento antecipado (10 bilhões de dólares) dos montantes sacados (20 bilhões) sob o pacote de 1998. Em meados de 2001, contudo, com o agravamento da crise argentina e o aparecimento de novas incertezas nos mercados financeiros, o Brasil retirou nova "fatia" da linha de crédito stand-by ainda aberta, agregando 2 bilhões de dólares às disponibilidades liberadas pelo acordo com o FMI. É verdade que o processo de estabilização se deu em meio a um dos mais vigorosos processos de reformas macroeconômicas conhecido pelo Brasil desde o início do governo militar, em 1964. A redução de gastos públicos foi combinada a um 
aumento de tributos poucas vezes vista na economia: elevação da CPMF de 0,2\% para 0,38\%, aumento da Cofins (Contribuição para o Financiamento da Seguridade Social) de 2\% para 3\%, crescimento das contribuições previdenciárias dos servidores públicos federais e, sobretudo e mais relevante, o projeto de uma Lei de Responsabilidade Fiscal (aprovada em 2000), que contribuiria para disciplinar os gastos públicos.

Para o Brasil, a dramática deterioração da situação econômica na Argentina, combinada a problemas conjunturais - crise energética durante a seca de 2001 - e a dificuldades estruturais - como a baixa competitividade externa, a despeito da desvalorização - representou uma ameaça real ao equilíbrio de um ciclo que vinha prometendo uma fase virtuosa. A política monetária, confrontada uma vez mais à ameaça de pressão inflacionária - em função da queda no câmbio, entre outros fatores - teve de fazer apelo novamente à prática dos juros altos, como forma de evitar uma excessiva fuga de capitais.

Nessas condições, começou a delinear-se a continuidade do programa de assistência financeira do FMI, que normalmente deveria encerrar-se em novembro de 2001 (depois de sete avaliações conduzidas com a instituição), o que foi efetivamente implementado em agosto desse ano, mediante novo acordo preventivo prevendo a liberação de mais de 15 bilhões de dólares (sendo 25\% na modalidade stand-by e o resto como $S R F$ ), para reforço de reservas internacionais e garantia contra novos ataques especulativos contra o Real. Pela utilização desse montante, o Brasil estava pagando entre 4,5\% e $5 \%$ de juros anuais por $25 \%$ do valor do empréstimo e 7,5\% pelo restante; no novo programa o País comprometia-se a elevar o superávit primário para 3,5\% do PIB para 2003 e 2004.

Esse novo acordo de empréstimo por parte do FMI - equivalente a cerca de 400\% da cota do Brasil junto ao Fundo e válido para o período de setembro de 2001 a dezembro de 2002 - deveria permitir cobrir, pelo menos parcialmente, as necessidades em divisas decorrentes de pagamentos devidos pelo serviço da dívida, pela amortização de títulos que venham à maturidade nesse período, bem como outras necessidades da balança de transações correntes, se os investimentos diretos não atingissem patamares satisfatórios em termos de volume e ritmo de entrada. Somados aos recursos disponíveis nas próprias reservas do País, bem como aos fluxos e disponibilidades das instituições multilaterais de crédito, esse montante deveria dar um horizonte de segurança à administração das contas públicas e externas do Brasil. De fato, a situação conheceu relativa estabilidade, a ponto de o Brasil se permitir pagar antecipadamente ao FMI, em abril de 2002, cerca de 4,2 bilhões de dólares, um montante similar ao que ele havia sacado preventivamente em setembro de 2001.

Em meados de 2002, no entanto, com o recrudescimento da crise no Cone Sul inexistência total de qualquer acordo entre a Argentina e o FMI, drenagem quase completa do sistema bancário uruguaio, com fechamento de agências e bloqueio de depósitos, como na Argentina, aliás -, ademais das incertezas derivadas do processo 
eleitoral brasileiro - que tendia a favorecer os candidatos presidenciais da oposição - ou do chamado "terrorismo econômico" provocado pelo pânico de inadimplência brasileira junto aos chamados "formadores de opinião do mercado" - também conhecidos como "especuladores de Wall Street" - o Brasil se viu, novamente, engolfado na voragem da crise financeira, com um declínio abrupto e significativo da paridade do real em relação ao dólar. Já no mês de junho, o governo decidiu sacar cerca de 10 bilhões de dólares do acordo em vigor, e obteve do FMI a redução do montante requerido como reservas de garantia (que então passaram de 20 a 15 bilhões de dólares).

Com a deterioração do cenário financeiro em decorrência do crescimento do candidato de oposição nas pesquisas eleitorais, o governo optou por negociar em pleno período de campanha, como tinha ocorrido em 1998, um novo acordo de sustentação financeira com o FMI, acertado em 7 de agosto de 2002, previamente à sua aprovação pela diretoria executiva do Fundo em setembro seguinte. É verdade que tanto os títulos da dívida brasileira quanto o valor externo do real tinham despencado dramaticamente no espaço de poucas semanas, antecipando, talvez, um cenário potencialmente catastrófico, como o que tinha acabado de ocorrer na Argentina. A despeito da divulgação de uma "carta ao povo brasileiro" em junho de 2002, na qual se comprometia a manter as linhas principais da política econômica em vigor e a respeitar os contratos internacionais do Brasil, o candidato Lula também prometia, em cima dos palanques, "mudar radicalmente a política econômica" seguida até então.

Segundo o novo acordo do Brasil com o FMI, que substituiu o anterior e foi o terceiro concluído na segunda administração FHC, o Brasil passou a dispor, por um período de 15 meses a partir de sua assinatura, de 30 bilhões de dólares adicionais (em torno de 23,4 bilhões de DES) para utilização em caso de necessidade, sendo que 20\% desse valor (em torno de 6 bilhões de dólares) poderiam ser utilizados já em 2002. Em estipulação suplementar ao acordo, o piso das reservas em divisas foi reduzido em 10 bilhões de dólares (para apenas 5 bilhões), o que liberou de imediato quantia equivalente para utilização na eventual amortização de obrigações externas do País ou para reforço das operações de intervenção do Banco Central nos mercados cambiais.

Em contrapartida, para garantir a sustentação fiscal dos novos arranjos, o governo FHC comprometeu-se a manter o nível do superávit primário em 3,75\% do PIB em 2003 (com uma elevação temporária para 3,9\% nos meses seguintes), com sua previsível recondução nas diretrizes orçamentárias de 2004 e 2005; também se previa a estabilização da dívida líquida do setor público em 59\% do PIB. Na verdade, o novo governo Lula, que assumiu em janeiro de 2003, estipulou, em sua primeira carta de intenções remetida pelo ministro da Fazenda Antônio Palocci ao diretor-gerente do FMI (em 28 de fevereiro), que tinha voluntariamente decidido elevar a meta do superávit para 4,25\%, com sugestão concomitante de manutenção desse nível até o final do governo, em 2006. Em meados do ano de 2003, consultas discretas foram mantidas pela equipe econômica para a conclusão de um novo acordo de sustentação financeira, 
independente do concluído em 2002, mas que se deveria situar na continuidade do anterior. ${ }^{7}$

\section{A ESQUERDA ANTI-FMI E O FIM DOS ACORDOS FORMAIS}

Desde 1958, o Brasil tinha contraído 17 operações de crédito junto ao FMI, em geral na modalidade de acordos stand-by. Quatro acordos sucessivos foram feitos entre 1998 e 2002, com revisões intermediárias e uma adicional, em 2003, quando o governo Lula reforçou o compromisso com o cumprimento das metas estabelecidas e aumentou voluntariamente o objetivo para o superávit primário, então fixado em 4,25\% do PIB (vide Tabela 2, in fine). Tamanho rigor fiscal não se via desde o início do regime militar, o que se entende como decorrência da desconfiança dos mercados em relação à boa gestão macroeconômica por parte de um governo cujos líderes, durante os vinte anos anteriores, prometiam desmantelar as bases da economia de mercado no Brasil. Essa conversão neoliberal foi bem recebida pelos mercados e pelas instituições de Bretton Woods.

O governo Lula ainda fez aprovar, em 2005, a extensão das metas de superávit primário para até 2007, como uma das garantias oferecidas para, nesse mesmo ano, não renovar, ou não negociar um novo acordo com o FMI. O Brasil passaria a ficar livre, portanto, das condicionalidades associadas aos acordos precedentes, mas se comprometia com o atingimento das metas fiscais previamente estabelecidas (como o superávit primário inscrito legalmente no orçamento). O governo também prometia implementar as reformas previdenciárias aprovadas no Congresso, além de empreender uma reforma tributária e colocar em vigor uma nova lei de falências (esta a única realizada). Todas as demais promessas, sobretudo as de redução dos gastos públicos, a diminuição da dívida pública, a melhoria do ambiente geral de negócios, com a diminuição dos entraves burocráticos e regulatórios ao empreendedorismo no Brasil, não foram implementadas ou sequer iniciadas. Quando ocorreram mudanças benéficas, como a elevação dos volumes de crédito na economia, isso se deu em detrimento do aumento da competitividade no mercado de capitais de empréstimo, com um aumento da participação do setor público na oferta total de crédito; a aprovação de uma lei de parcerias público-privadas, por exemplo, jamais teve aplicação prática.

Independentemente do abandono quase total das reformas estruturais, o governo Lula decidiu interromper - mais por razões políticas que econômicas - os entendimentos com o FMI, renunciando, assim, a linhas eventuais de crédito em divisas com custos notoriamente inferiores aos disponíveis nos mercados comerciais. ${ }^{8}$ Com efeito, não se pode deixar de registrar que as emissões de bônus soberanos pelo Brasil carregam uma taxa de risco (spread) sempre superiores às linhas de crédito - mesmo suplementares - do FMI. Em qualquer hipótese, a possibilidade de um apelo ao FMI em caso de necessidade, como uma nova crise financeira internacional ou uma deterioração 
sensível das contas externas, que colocasse em risco nossa capacidade de pagamento das obrigações externas (juros da dívida, amortização dos empréstimos contraídos, transferências de divisas por pagamento de fatores e outras saídas de capitais), sempre está presente no horizonte das possibilidades, mas o governo prefere, obviamente, agitar a bandeira da "soberania financeira".

Em apoio à decisão de 2005, ressalte-se que as contas externas do Brasil estavam relativamente em ordem, com amplo superávit comercial, o que permitia cobrir o déficit crônico dos serviços (e, portanto, das transações correntes) e outras saídas de capital. Os investimentos diretos estrangeiros também estavam sendo retomados, o que representava uma garantia adicional. Não havia, assim, necessidade, stricto sensu, de renovação do acordo. Mas o Brasil não deixa de exibir algumas fragilidades, internas e externas, como a grande dívida pública e a existência de déficit nominal no orçamento, mesmo com acúmulo de superávits primários (que não chegam, entretanto, a cobrir os pagamentos de juros da dívida pública). Nessa hipótese, um acordo com o FMI pode representar a garantia de saldo disponível, em caso de necessidade, e, sobretudo, um aval sobre a qualidade das políticas econômicas; ele também pode representar uma espécie de sinal de alerta sobre a fragilidade de nossas contas externas. Em última instância, cabe ao próprio Brasil realizar os esforços necessários para colocar as contas públicas, sobretudo as internas, em condições de sustentabilidade permanente, o que os economistas do Fundo não deixam de lembrar a cada vez.

\section{CONCLUSÕES: 70 ANOS DE UM RELACIONAMENTO ERRÁTICO}

Os setenta anos que nos separam da conferência de Bretton Woods conheceram duas fases básicas do sistema monetário internacional: as três primeiras décadas, caracterizadas, grosso modo, pelas tentativas nem sempre bem-sucedidas de manutenção do esquema de estabilidade cambial acordado em 1944, com base na preservação de uma paridade fixa entre o dólar e o ouro, e na adesão correspondente de todas as demais moedas a essa relação fundamental, e o "não sistema” conhecido desde 1973, de eliminação formal dessa obrigação e de flutuação não administrada das moedas dos países membros, o que implicou novas modalidades de apoio emergencial do FMI aos países enfrentando dificuldades de balanço de pagamentos. O Brasil atravessou todas essas fases, com um respeito muito incompleto, e geralmente frustrado, das regras e condicionalidades estabelecidas pelo FMI ao longo de uma dependência que se estendeu desde a primeira fase - quando sequer se respeitou o princípio da unicidade cambial até o início do presente milênio.

Essa longa trajetória, que também reproduziu o itinerário errático das políticas econômicas do Brasil - geralmente expansivas e desenvolvimentistas -, não foi caracterizada por uma conformidade do País ao chamado "modelo de Bretton Woods", bem mais ortodoxo, em suas principais determinações econômicas, do que o efetivamente 
seguido pelos governos brasileiros, tanto sob o regime autoritário quanto na fase democrática recente. Numa primeira fase, o Brasil, junto com alguns outros países na mesma situação, insistia que as instituições de Bretton Woods precisavam incorporar a dimensão do desenvolvimento em seus programas de ajuste financeiro, o que só foi alcançado muito parcialmente (e de forma mais abrangente no sistema multilateral de comércio, que agregou o conceito de tratamento diferencial e mais favorável para países em desenvolvimento). Uma segunda fase, de relacionamento quase conflituoso, ocorreu durante os grandes desequilíbrios externos e processos de aceleração inflacionária dos anos 1970 a meados dos 1990, com encontros e desencontros em torno de sucessivos acordos stand-by. Finalmente, no novo milênio, o Brasil conseguiu superar a dependência - inclusive porque assumiu seriamente a responsabilidade por ajustes nas contas internas - mas também contraiu com o FMI o encargo de produzir superávits primários no orçamento doméstico, como forma de estabilizar as obrigações governamentais no quesito da dívida pública.

O período recente, caracterizado pelo acúmulo de reservas internacionais - até mais do que seria necessário para cobrir importações -, vem sendo marcado pela insistência do Brasil na atribuição de maior dotação nos capitais constitutivos das duas organizações de Bretton Woods, aspiração que vem sendo dificultada pela relutância de diversos países europeus em ver diminuída sua participação no processo decisório. Em todo caso, o Brasil entrou em uma nova fase de seu relacionamento de 70 anos com o FMI e o Banco Mundial, não mais submetido - pelo menos nas condições prevalecentes do início da segunda década dos anos 2000 - à antiga condição de dependência, podendo até exibir uma nova faceta, a de credor moderado do Fundo. Cabe registrar, contudo, que a continuidade ou o agravamento dos desequilíbrios nas contas internas e dos déficits nas transações correntes, acrescidos do endividamento privado mercantil - que tem, de toda forma, de ser coberto pela disponibilidade de divisas administradas pelo Banco Central - pode gerar nova situação de fragilidade financeira externa, a despeito mesmo das reservas acumuladas, com potencial para fazer o País retroceder a fases outrora conhecidas em sua história financeira. A história nunca se repete da mesma forma, mas episódios de crises financeiras, em todas as dimensões e contextos conhecidos, são recorrentes no itinerário contraditório da economia mundial, envolvendo tanto países avançados quanto economias emergentes. Em última instância, o registro histórico indica que o Brasil, por uma combinação de conjuntura externa desfavorável ou equívocos de política econômica, não se encontra ao abrigo de novas recaídas num eventual cenário de crise financeira. 


\section{NOTAS}

* O autor agradecer a apresentação de sugestões e de correções pelos pareceristas anônimos, bem como o competente trabalho de revisão formal efetuado no seguimento.

1 Este artigo conta, para além da análise da literatura secundária, com uma revisão de fontes primárias e de materiais constantes do acervo pessoal do autor, envolvendo negociações e discussões preparatórias para negociações internacionais nesta área da política financeira externa do Brasil. Destaca-se, em especial, o acompanhamento direto do assunto como chefe da Divisão de Política Financeira do Itamaraty, nos anos 1995 a 1999 e, depois, na Embaixada do Brasil em Washington, de 1999 a 2003. Todas as posições aqui apresentadas são, no entanto, de responsabilidade exclusiva do autor.

2 Cabe registrar que a Argentina fez reserva da resolução $V$, que recomendava a cessação de relações comerciais e financeiras com os países agressores (FINALACT, 1942, p. 57).

3 O relatório do grupo foi publicado como: William Fellner, Fritz Machlup, Robert Triffin, and others, Maintaining and Restoring Balance of International Payments (Princeton: Princeton University Press, 1966); apud CONNELL, 2013.

4 A partir de 1981, o SDR, que consolidou-se como a moeda de referência do FMI, passou a ser baseado unicamente num coquetel representado por cinco moedas: o dólar americano (42\%), o marco alemão (19\%), o iene japonês, a libra britânica e o franco francês (13\% cada uma); o marco alemão e o franco francês passaram a ser representados pelo euro, quando de sua introdução, mas as proporções entre as moedas foram sendo alteradas ao longo do tempo.

5 Em 1946, por exemplo, no momento de sua entrada no sistema do FMI, a libra britânica já tinha sido desvalorizada de US \$ 4,86 para US\$ 4,03, seguindo-se nova e importante desvalorização em setembro de 1949, de US\$ 4,02 para US \$ 2,80, num movimento que deslanchou a desvalorização de 25 outras moedas; em novembro de 1967, outra crise da libra estabelece a sua nova paridade em US\$2,40, indicando que o mundo de Bretton Woods estava sendo irremediavelmente alterado.

6 A Universidade de Princeton organizou diversos encontros para examinar a questão, publicando os resultados em seguida: Stephen Harris, The bürgenstock communiqué: a critical examination of the case for limited flexibility of exchange rates, essays in international finance n. 80 (Princeton University, International Finance Section, 1970); Franco Modigliani e Hassein Askari, The reform of the international payments system, essays in international finance n. 89 (Princeton University, International Finance Section, 1971).

7 Segundo anunciado em 5 nov. 2003 pelo Ministério da Fazenda, o novo acordo de aproximadamente US\$ 14 bilhões - US $\$ 8$ bilhões referentes à parcela anterior não sacada e mais US\$ 6 bilhões extras - proposto pelo governo brasileiro ao FMI estendia a negociação e os desembolsos até 2007. Como o acordo anterior de US\$ 30 bilhões, firmado em 2002, previa um prazo de vigor até 2006, a nova negociação permitiria a extensão dos desembolsos e saques por mais um ano. O acordo com o FMI previa três desembolsos diferenciados: um de aproximadamente US\$ 12 bilhões em 2005, outro de mais US\$ 8 bilhões para 2006 e mais US \$ 2,5 bilhões em 2007 (disponível em < http://www.fazenda.gov.br/ portugues/releases/2003/r031106.asp>).

8 Em 13 dez. 2005, o Brasil anunciou sua intenção de efetuar um pagamento antecipado ao Fundo, correspondendo a um montante DES/SDR 10.79 bilhões (US \$ 15.46 bilhões); as obrigações pendentes do Brasil tinham sido contraídas sob o acordo stand-by de 2002, ampliado em 2003 (disponível em: < http://www.imf.org/external/ $\mathrm{np} / \mathrm{sec} / \mathrm{pr} / 2005 / \mathrm{pr} 05275 . \mathrm{htm}>$ ). 


\section{REFERÊNCIAS BIBLIOGRÁFICAS}

ALMEIDA, Paulo Roberto de. Finanças internacionais do Brasil: uma perspectiva de meio século (1954-2004). In: SARAIVA, José Flávio Sombra; CERVO, Amado Luís (Orgs.), O crescimento das relações internacionais no Brasil. Brasília: Instituto Brasileiro de Relações Internacionais, 2005, p. 231-270.

O Brasil e as crises financeiras internacionais, 1929-2001. In: ALMEIDA, Paulo Roberto de. Os primeiros anos do século XXI: o Brasil e as relações internacionais contemporâneas. São Paulo: Editora Paz e Terra, 2002. p. 189-232.

. O Brasil e o sistema de Bretton Woods: instituições e políticas em perspectiva histórica, 1944-2002. In: MAZZUOLI, Valério de Oliveira; SILVA, Roberto Luiz (Orgs.), O Brasil e os acordos econômicos internacionais: perspectivas jurídicas e econômicas à luz dos acordos com o FMI. São Paulo: Editora RT, 2003. p. 30-64.

. Relações internacionais e política externa do Brasil: a diplomacia brasileira no contexto da globalização. Rio de Janeiro: LTC, 2012.

ARAÚJO, João Hermes Pereira de. Oswaldo Aranha e a diplomacia. In: CAMARGO, Aspásia; ARAÚJO, João Hermes Pereira de; SIMONSEN, Mário Henrique. Oswaldo Aranha: a estrela da revolução. São Paulo: Mandarim, 1996, p. 105-379.

BAER, Monica. A dívida externa brasileira: estratégias de negociação e impactos internos (1983-1987). In: PEREIRA, Luiz Bresser (Org.). Dívida Externa: crise e soluções. São Paulo: Brasiliense, 1989, p. 184-218.

BARREIROS, Daniel de Pinho. Atuação da Delegação Brasileira na Formulação do Acordo Internacional de Bretton Woods (1942-1944), História 28 (2). São Paulo, 2009, p. 515-570. Disponível em:

<http://www.scielo.br/pdf/his/v28n2/18.pdf>. Acesso em 20 jul. 2014.

BATISTA JR., Paulo Nogueira. Da crise internacional à moratória. Rio de Janeiro: Paz e Terra, 1988.

BERGSMAN, Joel. Brazil: industrialization and trade policies. Londres: Oxford University Press, 1970.

. A política comercial no pós-guerra. In: VERSIANI, Flávio Rabelo; BARROS, José Roberto Mendonça de (Orgs.), Formação econômica do Brasil, a experiência da industrialização. São Paulo: Saraiva, 1977, p. 391-410. BERNSTEIN, Edward M.. International effects of U.S. economic policy (Materials prepared in connection with the Study of Employment, Growth, and Price Levels for Consideration by the Joint Economic Committee, 86 Congress, 2 session. 1960.

BIDERMAN, Ciro; COZAC, Luis Felipe L.; REGO, José Marcio. Conversas com economistas brasileiros. São Paulo: Editora 34, 1996, cap. 1. CAMPOS, Roberto de Oliveira, p. 31-59.

BLACK, Stanley W. A levite among the priests: Edward M. Bernstein and the origins of the Bretton Woods system. Boulder: Westview Press, 1991.

BLUSTEIN, Paul. The chastening: inside the crisis that rocked the global financial system and humbled the IMF. New York: Public Affairs, 2001.

BOUGHTON, James M. Silent revolution: the international monetary fund, 1979-1989. Washington: International Monetary Fund, 2001.

CERQUEIRA, Ceres Aires. Dívida externa brasileira: processo negocial, 1983-1996. Brasília: Banco Central do Brasil, 1997.

CONNELL, Carol M.. Reforming the world monetary system: Fritz Machlup and the Bellagio group. London: Pickering \& Chatto, 2013 .

CRUZ, Paulo Davidoff. Dívida externa e política econômica: a experiência brasileira nos anos setenta. São Paulo: Brasiliense, 1984.

FINAL ACT of the Third Meeting of the Ministers of Foreign Affairs American Republics. Rio de Janeiro, Brasil, 15 a 28 de Janeiro de 1942. Disponível em: < http://www.oas.org/council/meetings\%20of\%20consultation/actas/acta\%203.pdf> Acesso em: 20 jul. 2014.

FRIEDMAN, Milton. The case for flexible exchange rates. Essays in positive economics. Chicago: The University of Chicago Press, 1953, p. 157-203.

GAROFALO FILHO, Emilio. Câmbio, ouro e dívida externa, de Figueiredo a FHC. São Paulo: Saraiva, 2002.

HAZLITT, Henry. From Bretton Woods to world inflation: a study of causes and consequences. Chicago: Regnery Gateway, 1984.

HUDDLE, Donald L. Balanço de pagamentos e controle de câmbio no Brasil, diretrizes políticas e história, 19461954, In: VERSIANI, Flávio Rabelo; BARROS, José Roberto Mendonça de (Orgs.), Formação econômica do Brasil, a experiência da industrialização. São Paulo: Saraiva, 1977, p. 357-389.

IANNI, Otávio. Estado e planejamento econômico no Brasil, 1930-1970. Rio de Janeiro: Civilização Brasileira, 1971. KINDLEBERGER, Charles. Manias, panics, and crashes: a history of financial crises. New York: Basic Books, 1978. KRAUZE, Lawrence B.. Sequel to Bretton Woods: a proposal to reform de world monetary system. Washington: The Brookings Institution Staff Paper, 1971. 
MAZZUOLI, Valério de Oliveira; SILVA, Roberto Luiz (Orgs.). O Brasil e os acordos econômicos internacionais: perspectivas jurídicas e econômicas à luz dos acordos com o FMI. São Paulo: Editora RT, 2003.

MEYER, Arno. As negociações da dívida externa do Brasil no âmbito do Clube de Paris, In: BELUZZO, Luiz Gonzaga de Mello; BATISTA JR., Paulo Nogueira (Orgs.), A Luta pela sobrevivência da moeda nacional: ensaios em homenagem a Dilson Funaro. Rio de Janeiro: Paz e Terra, 1992, p. 51-90.

MONTEIRO, Jorge Vianna. Lições de economia constitucional brasileira. Rio de Janeiro: Editora FGV, 2004.

MOREIRA, Marcílio Marques. Diplomacia, política e finanças: De JK a Collor: 40 anos de história por um de seus protagonistas. Rio de Janeiro: Objetiva, 2001.

OLIVEIRA, Gesner. Brasil-FMI: frustrações e perspectivas. São Paulo: Bienal, 1993.

PEREIRA, José Eduardo Carvalho. Financiamento externo e crescimento econômico no Brasil: 1966/73. Rio de Janeiro: IPEA/INPES, 1974.

PEREIRA, Luiz Carlos Bresser. The debt problem: pospone it or Solve it?, Revista de economia política vol. 8, n. 4, outubro 1989. In: PEREIRA, Luiz Carlos Bresser (Org.). Dívida Externa: crise e soluções. São Paulo: Brasiliense, 1989. p. 241-246.

Uma estratégia alternativa para negociar a dívida externa, XIV Congress of Latin American Studies Association (New Orleans). In: Senhor n. 380, 4/07/1988. p. 46-47; In: PEREIRA, Luiz Carlos Bresser. Dívida externa: crise e soluções, op. cit., 1989. p. 219-237.

PORTELLA FILHO, Petrônio. A moratória soberana: a alternativa do confronto externo, seus custos, perspectivas e mitos. São Paulo: Alfa-Omega, 1988.

TRIFFIN, Robert. Europe and the money muddle: from bilateralism to near convertibility, 1947-1956. London: Oxford University Press, 1957.

Gold and the dollar crisis: the future of convertibility. New Haven: Yale University Press, 1960.

VIANNA, Sergio Besserman. Duas tentativas de estabilização: 1951-1954. In: ABREU, Marcelo de Paiva (Org.), A ordem do progresso: cem anos de política econômica republicana, 1889-1989. Rio de Janeiro: Campus, 1989, p. 123-150.

TABELA 2 - BRASIL: ACORDOS FORMAIS ESTABELECIDOS COM O FMI, I958-20IO

\begin{tabular}{lllllll}
$\begin{array}{l}\text { DATA DO } \\
\text { ACORDO }\end{array}$ & $\begin{array}{l}\text { TIPO DE } \\
\text { ACORDO }\end{array}$ & $\begin{array}{l}\text { EXPIRAÇÃO } \\
\text { CANCELAMENTO }\end{array}$ & $\begin{array}{l}\text { QUANTIA } \\
\text { (DES MILHÕES) }\end{array}$ & $\begin{array}{l}\text { QUANTIA } \\
\text { SACADA }\end{array}$ & $\begin{array}{l}\text { QUANTIA } \\
\text { NÃO SACADA }\end{array}$ & $\begin{array}{l}\text { MINISTRO } \\
\text { DA FAZENDA }\end{array}$ \\
\hline 03.06 .58 & STAND-BY & 02.06 .59 & 37,50 & 37,50 & - & LUCAS LOPES \\
\hline 18.05 .61 & STAND-BY & 17.05 .62 & 160,00 & 60 & 100,0 & CLEMENTE MARIANI \\
\hline 13.01 .65 & STAND-BY & 12.01 .66 & 125,00 & 75,00 & 50,00 & GOUVÊA BULHÕES \\
\hline 01.02 .66 & STAND-BY & 31.01 .67 & 125,00 & - & 125,00 & GOUVÊA BULHÕES \\
\hline 13.02 .67 & STAND-BY & 12.02 .68 & 30,00 & - & 30,00 & GOUVÊA BULHÕES \\
\hline 29.04 .68 & STAND-BY & 28.04 .69 & 87,50 & 75,00 & 12,50 & DELFIM NETTO \\
\hline 29.04 .69 & STAND-BY & 04.02 .70 & 50,00 & - & 50,00 & DELFIM NETTO \\
\hline 04.02 .70 & STAND-BY & 03.02 .71 & 50,00 & - & 50,00 & DELFIM NETTO \\
\hline 04.02 .71 & STAND-BY & 03.02 .72 & 50,00 & - & 50,00 & DELFIM NETTO \\
\hline 03.03 .72 & STAND-BY & 02.03 .73 & 50,00 & - & 50,00 & DELFIM NETTO \\
\hline
\end{tabular}




\begin{tabular}{lllllll}
01.03 .83 & EFF(2) & 28.02 .86 & $4.239,38$ & $2.743,13$ & $1.496,25$ & DELFIM NETTO(3) \\
\hline 23.08 .88 & STAND-BY & 28.02 .90 & $1.096,00$ & 365,30 & 730,70 & MAILSON NÓBREGA \\
\hline 29.02 .92 & STAND-BY & 31.08 .93 & $1.500,00$ & 127,50 & $1.372,50$ & MARCÍLIO MOREIRA \\
\hline 13.11 .98 & STAND-BY & 23.08 .01 & 3.907 .00 & $2.958,00$ & 948,00 & PEDRO S. MALAN \\
\hline 13.11 .98 & SFR(4) & 10.04 .01 & $9.117,56$ & $6.512,65$ & $2.604,90$ & PEDRO S. MALAN \\
\hline 14.09 .01 & STAND-BY & 14.12 .02 & $12.144,00$ & $7.700,00(5)$ & $4.444,00$ & PEDRO S. MALAN \\
\hline $06.09 .02(6)$ & STAND-BY & 31.12 .03 & $22.800,00$ & $5.300,00$ & $17.500,00$ & PEDRO S. MALAN \\
\hline 14.03 .03 & STAND-BY & 31.12 .03 & 3.000 .000 & - & (RESERVAS) & ANTÔNIO PALOCCI \\
\hline 13.12 .05 & PAGAMENTO(7) & - & $10.790,00$ & - & - & ANTÔNIO PALOCCI \\
\hline 22.01 .10 & EMPRÉSTIMO AO FMI & US\$ $10 \mathrm{BI}$ & $(\grave{A}$ DISPOSIC̣ÃO DO FMI) (8) & GUIDO MANTEGA \\
\hline
\end{tabular}

(1) DES (Direito Especial de Saque, ou SDR, em inglês) = US\$ 1,36; para o período anterior à criação dos DES (1967-1970) trata-se do equivalente em dólares dos Estados Unidos;

(2) Extended Fund Facility, instrumento de saque criado por programa específico do FMI;

(3) Ministro do Planejamento encarregado dos organismos internacionais;

(4) Supplemental Reserve Facility;

(5) Saque efetuado em 21.06.2002, dos quais DES 3,3 bilhões em linha SRF;

(6) Valor em dólares: 31,4 bilhões;

(7) Brasil efetua o pagamento dos montantes colocados à sua disposição pelo FMI nos dois acordos anteriores, por um valor equivalente a US\$15,46 bilhões;

(8) Brasil se dispõe a comprar até US\$ 10 bilhões em notas a serem eventualmente emitidas pelo FMI.

Fontes: Relatórios anuais do FMI; pesquisas do autor; Nota: Um sumário de todas as transações financeiras entre o Brasil e o FMI, de 1984 a 2011, pode ser visto neste link: <http://www.imf.org/external/np/fin/tad/extrans1.aspx?memberKey1=90\&endDate= 2011-05-30\&finposition_flag=YES>. Acesso em 20 jul. 2014.

Paulo Roberto de Almeida

pralmeidalame.com |

Diplomata DE CARREIRA PROFESSOR NO PROGRAMA DE MESTRADO E DOUTORAMENTO EM Direito do Centro Universitário de Brasília (Uniceub) 
